University of Michigan Law School

University of Michigan Law School Scholarship Repository

5-1977

\title{
Judicial Review of Labor Arbitration Awards: A Second Look at Enterprise Wheel and Its Progeny
}

Theodore J. St. Antoine

University of Michigan Law School, tstanton@umich.edu

Follow this and additional works at: https://repository.law.umich.edu/articles

Part of the Courts Commons, Dispute Resolution and Arbitration Commons, Labor and Employment Law Commons, and the Supreme Court of the United States Commons

\section{Recommended Citation}

St. Antoine, Theodore J. "Judicial Review of Labor Arbitration Awards: A Second Look at Enterprise Wheel and Its Progeny." Mich. L. Rev. 75 (1977): 1137-61.

This Essay is brought to you for free and open access by the Faculty Scholarship at University of Michigan Law School Scholarship Repository. It has been accepted for inclusion in Articles by an authorized administrator of University of Michigan Law School Scholarship Repository. For more information, please contact

mlaw.repository@umich.edu. 


\title{
JUDICIAL REVIEW OF LABOR ARBITRATION AWARDS: A SECOND LOOK AT ENTERPRISE WHEEL AND ITS PROGENY ${ }^{\dagger}$
}

\author{
Theodore J. St. Antoine*
}

\section{INTRODUCTION}

Logic, so the cliche goes, is not the life of the law. But logic is very much like the DNA of the law-the structural principle without which all is sprawl and muddle. In the last ten years a controversy has raged over the role of the labor arbitrator in issuing awards, and the role of the courts in reviewing and enforcing those awards. This controversy has largely taken the form of a continuing debate among scholars and practicing arbitrators at the annual meetings of the National Academy of Arbitrators. With due respect to the thoughtful and experienced persons who have contributed to this debate during the past decade, I think that a fundamental illogicality has pervaded these discussions.

The error, as I see it, is that we have tried to impose a personal vision on a process that is not of our making. Thus, some worry about the validity and finality of arbitral awards and argue that arbitrators should seek guidance from statutory law in order to reduce the likelihood of challenge in the courts. ${ }^{1}$ Others examine arbitrators' professional credentials and conclude they are not up to the task of construing statutes, even if the courts would permit them to do it. $^{2}$ Still others stress the undoubted role of the arbitrator as part

$\dagger$ This essay is based on an address delivered at the Thirtieth Annual Meeting of the National Academy of Arbitrators, Toronto, Canada, April 14, 1977.

* Dean and Professor of Law, The University of Michigan. A.B. 1951, Fordham College; J.D. 1954, The University of Michigan.-Ed.

The author gratefully acknowledges the research assistance of Linda Witte-Van Harken of The University of Michigan Law School class of 1978.

1. Howlett, The Arbitrator, the NLRB, and the Courts, in Proc. of THE 20TH annual Meeting, National Academy of Arbitrators, The Arbitrator, the NLRB, AND THE COURTs 67 (D. Jones ed. 1967) [hereinafter cited as ARBITRATOR]; Mittenthal, The Role of Law in Arbitration, in Proc. OF THE 21sT ANNUAL MEETING, National ACADEMY OF ARBItrators, Developments IN AMERICAN AND FoREIGN ARBITRation 42 (C. Rehmus ed. 1968) [hereinafter cited as DeVElopMENTs]. But cf. Meltzer, Ruminations About Ideology, Law, and Labor Arbitration, in ARBITRATOR, supra at 1.

2. Edwards, Arbitration of Employment Discrimination Cases: An Empirical Study, in Proc. of the 28th ANNual MeEting, National Academy of ARBitraTORS, ARBITRATION-1975, at 59 (B. Dennis \& G. Somers eds. 1976). 
and parcel of the ongoing collective bargaining process and insist that insofar as arbitrators embark upon the totally different mission of statutory interpretation, their awards will lose the deference traditionally accorded them by the courts. ${ }^{3}$ I too have been guilty of this effort to impose a personal vision. In an early round of the debate, I drew what I now consider a quite inadequate distinction between judicial review of an arbitral award based wholly on contract interpretation and judicial review of an arbitral award based at least in part on statutory interpretation. ${ }^{4}$

This essay is an effort to restore a logical perspective to labor arbitration and to clarify the respective roles of the arbitrator and the courts. I shall first present a concept of the arbitrator as "contract reader," then consider the statutory and decisional support for this concept-with emphasis on the landmark Enterprise Wheel case -and, finally, examine the recognized grounds for a judicial refusal to enforce an arbitrator's decision.

\section{The Arbitrator as Contract "Reader" AND THE NEW GOLDEN AGE}

In a brilliant and provocative paper presented at the 1976 meeting of the National Academy, Professor David Feller dolefully proclaimed the imminent end of arbitration's golden age." He maintained that the deference customarily paid arbitral awards by the courts cannot be fully explained by any special expertise possessed by arbitrators or by any special speed or economy possessed by the process. Instead, he contends that this deference "derives from a not always explicitly stated recognition that arbitration is not a substitute for judicial adjudication, but a part of a system of industrial selfgovernance." ${ }^{\circ}$ In other words, the key to the special status of labor arbitration is that it is an integral component of union and management's autonomous regulation of their ongoing relationship. The courts do not try to substitute their judgments for that of the arbitrator's because they cannot. Courts can only adjudicate according to preexisting substantive standards. In contrast, it is of the essence of labor arbitration that the arbitrator's most critical function is to

3. Feller, The Coming End of Arbitration's Golden Age, in Proc. of THE 29 TH annual Meeting, National Academy of Arbitrators, Arbitration-1976, at 97 (B. Dennis \& G. Somers eds. 1976) [hereinafter cited as ARBITRATION-1976].

4. St. Antoine, Discussion-The Role of Law in Arbitration, in DEveloPMENTS, supra note 1 , at 75,82 .

5. Feller, supra note 3.

6. Id. at 107 . 
apply a set of rules governing the union-employer relationship that are "integral with and cannot be separated from the machinery that the parties have established to resolve disputes as to their meaning."7 The arbitrator's award is not so much an interpretation of the collective bargaining agreement as an organic extension, a fulfillment, a flowering of the seed it planted. The standards governing the arbitrator's typical award under a collective bargaining agreement are at least as much process-oriented as substance-oriented. The converse, of course, as Feller would have it, is that arbitration immediately loses its peculiar magic and status as soon as it undertakes (as it has increasingly undertaken) the interpretation and application of "external law," i.e., statutory and decisional law, the heretofore exclusive domain of the courts, presumably the kind of law, as distinguished from that of the collective bargaining agreement, that provides every adjudicating court with a univocal, definitive standard of judgment.

Professor Feller's address and his masterful article on the collective bargaining agreement ${ }^{8}$ offer fresh, penetrating insights into the nature of labor arbitration as it has developed in this country. I am convinced, however, that some of his basic conclusions-that the collective bargaining agreement, except for its arbitration clause, is not a judicially enforceable contract, and that arbitration awards derive their authoritativeness in the judicial arena from the processinvolvement of the arbitrator and from the absence of substantive contractual standards-are at best just partly true, and at worst highly misleading. I shall deal only with the asserted basis for the courts' deference to arbitration.

To restore perspective to this issue, we must be prepared to accept the necessary and logical implications of a premise that probably none of us disputes. Labor arbitration as we know it is not the product of the intellectualizing of the National Academy, nor even of the mythologizing of Justice Douglas. ${ }^{9}$ It is the product of contract-or, more precisely, the product of the particular contracts of particular parties. These contracts may vary widely in the scope of the matters entrusted to final and binding arbitration. The appropriate scope of judicial review and enforcement of arbitral awards

7. Id. at 101.

8. Feller, A General Theory of the Collective Bargaining Agreement, 61 CaLIF. L. REv. 663 (1973).

9. Justice Douglas's encomium is inscribed most memorably, of course, in the Steelworkers Trilogy, Steelworkers v. American Mfg. Co., 363 U.S. 564 (1960); Steelworkers v. Warrior \& Gulf Naviagtion Co., 363 U.S. 574 (1960); Steelworkers v, Enterprise Wheel \& Car Corp., 363 U.S. 593 (1960). 
under such contracts will thus also vary widely. Yet, except for certain considerations of basic public policy, to be discussed later, ${ }^{10}$ it is the parties themselves, unions and employers, who should supply the answers to the questions that have so beset the arbitration profession throughout the past decade. As interested bystanders, arbitrators are entitled to suggest to the parties what answers they might regard as wisest and most prudent. But once we have accepted an arbitral assignment in a given case, our own views should be irrelevant. The parties' views, as best we can discern them, should control.

Put most simply, the arbitrator is the parties' officially designated "reader" of the contract. He (or she) is their joint alter ego for the purpose of striking whatever supplementary bargain is necessary to handle the anticipated unanticipated omissions of the initial agreement. Thus, a "misinterpretation" or "gross mistake" by the arbitrator becomes a contradiction in terms. In the absence of fraud or an overreaching of authority on the part of the arbitrator, he is speaking for the parties, and his award is their contract. That is what the "final and binding" language of the arbitration clause says. In sum, the arbitrator's award should be treated as though it were a written stipulation by the parties setting forth their own definitive construction of the labor contract. ${ }^{11}$

This thesis that the arbitrator is a contract "reader" helps clarify the proper scope of judicial review of an arbitrator's decision. The explanation of the courts' deference to arbitral awards is not to be

10. See text at notes $84-97$ infra.

11. I can think of one likely exception to this equation of award and agreement. In Boys Markets, Inc. v. Retail Clerks Local 770, 398 U.S. 235 (1970), the Supreme Court overruled Sinclair Refining Co. v. Atkinson, 370 U.S. 195 (1962), and authorized the federal courts to issue injunctions, despite the Norris-LaGuardia Act, against strikes by unions over grievances that could be submitted to final and binding arbitration. Even before Boys Markets, however, courts were prepared to specifically enforce an arbitrator's award ordering a union to cease striking in violation of contract, although under Sinclair the parties' own clear no-strike clause would not have been subject to specific enforcement. See, e.g., New Orleans Steamship Assn. v. Longshoremen's Local 1418, 389 F.2d 369 (5th Cir.), cert. denied, 393 U.S. 828 (1968). I assume this approach will be followed, even though it does not necessarily fit the rationale of Boys Markets, which was based on the notion that a union could be enjoined from striking over a matter subject to arbitration at the behest of the union. Cf. Buffalo Forge Co. v. Steelworkers, 428 U.S. 397 (1976) (district court not empowered to enjoin sympathy strike over issue not subject to arbitration pending arbitrator's decision as to whether strike was in violation of a no-strike clause). If I am correct, the effect will be to create one category of arbitral awards, i.e., those ordering the halt of a union's strike in breach of contract, which will have greater judicial enforceability than the parties' own contract. This apparent anomaly may be explained by the underlying Norris-LaGuardia policy against direct judicial intervention into labor disputes, since here the arbitrator constitutes a buffer between the court and the parties. 
found in some unique element of the collective bargaining process. The real explanation is simpler, more profound, and more conventional. Courts will ordinarily enforce an arbitral award because it is part of the parties' contract, and, with certain well-recognized limitations, courts are in the business of enforcing contracts. The doctrine that the arbitrator's decision is "final and binding" is qualified in several respects, as I shall discuss later. But, as the parties have given the arbitrator the task of reading the contract, the court need have no qualms about enforcing an award that appears to the court to be at odds with the parties' agreement.

Confirmation that the parties' agreement, and not something peculiar to collective bargaining, is the key to judicial deference is to be found in the treatment accorded commercial arbitration awards. In a line of decisions extending far back before the Steelworkers Trilogy, ${ }^{12}$ the courts have held that they will not review the merits of arbitral awards in commercial settings and will look only at procedural fairness, fraud, partiality, or total irrationality. The contractual nature of the arbitration process is stressed in most opinions. ${ }^{13}$ Following the Trilogy's establishment of a federal standard for review in labor arbitration cases, some courts in enforcing commercial arbitration awards have sought to apply the same standard, ${ }^{14}$ while others have thought they were applying a standard either more ${ }^{15}$ or less $^{16}$ likely to result in an overturning of the commercial arbitration award.

I see nothing anomalous in according an arbitral award greater finality, in either a labor or commercial context, than would be accorded a trial court's construction of the selfsame contract. Customarily, parties to a contract containing no arbitration provision do not agree that the trial court's interpretation shall be "final and binding." If, to save time, money, or effort, the parties did include such

12. Cases cited in note 9 supra.

13. See, e.g., Burchell v. Marsh, 58 U.S. (17 How.) 344 (1855); Park Constr. Co. v. Independent School Dist., 216 Minn. 27, 11 N.W.2d 649 (1943); Harrell v. Dove Mfg. Co., 234 Ore. 321, 381 P.2d 710 (1963). Cases are collected in 5 AM. Jur. 2d Arbitration \&.Award $\S 167$ (1962); 6 C.J.S.2d Arbitration $\S 2$, at 162-64 (1975).

14. E.g., Lentine v. Fundaro, 29 N.Y.2d 382, 278 N.E.2d 633, 328 N.Y.S.2d 418 (1972); Morris v. Zuckerman, 69 Cal. 2d 686, 446 P.2d 1000, 72 Cal. Rptr. 880 (1968).

15. E.g., Swift Indus, v. Botany Indus., 466 F.2d 1125 (3d Cir. 1972) (award may not stand unless it meets test of rationality).

16. E.g., O.S. Corp. v. Samuel A. Kroll, Inc., 29 Md. App. 406,348 A.2d 870 (Ct. Spec. App. 1975) (award upheld unless completely irrational or subject to an apparent impropriety). 
a provision, I would expect an appellate court to honor that limitation on its reviewing authority. ${ }^{17}$

The point of all this, of course, is that (within limits) the parties are the masters of their own contract. The appropriate scope of judicial review should be determined by the particular agreement in any case, not by anything inherent in the arbitration or collective bargaining process. I should have thought this was pretty clear from Enterprise Wheel ${ }^{18}$ itself. For all the bouquets thrown arbitrators and arbitration by Justice Douglas, it is ultimately the "collective bargaining agreement" from which an award must "draw its essence" in order to be valid and enforceable. ${ }^{10}$

Recognition of the arbitrator as the parties' official "reader" of the contract-no more and no less-would also enable us to dispose of many of the conundrums that have plagued the National Academy over the past decade. It clearly would resolve the perennial question of what the arbitrator should do when confronted with an irreconcilable conflict between the parties' agreement and "the law." With a right good conscience, he should follow the contract. After all, he is not responsible for "enforcing" an illegal or invalid contract. Only courts can enforce contracts. All the arbitrator is asked for is a definitive parsing of the parties' own agreement regarding the matter in dispute-or, more realistically, of the putative agreement they would have reached if they had ever anticipated the issue that has now arisen. This preference for contract over "law" also seems supported by Enterprise Wheel's declaration that an arbitrator exceeds the scope of his submission if he bases his decision on his view of the "requirements of enacted legislation."20 Furthermore, the notion of arbitrator as contract reader permits of no distinction between an award upholding conduct contrary to law and an award ordering conduct contrary to law. In either instance, the arbitrator's mandate is plain: tell the parties (and the courts) what the contract means and let them worry about the legal consequences.

I do not wish to appear perverse in urging arbitrators to engage in the futility of rendering unenforceable awards. But as I stated at greater length elsewhere, ${ }^{21}$ the law is often not all that clear. The

17. Cf. United States Consol. Seeded Raisin Co. v. Chaddock \& Co., 173 F. 577 (9th Cir. 1909), cert. denied, 251 U.S. 591 (1910) (agreement not to appeal valid and enforceable).

18. Steelworkers v. Enterprise Wheel \& Car Corp., 363 U.S. 593 (1960).

19. 363 U.S. at 597.

20. 363 U.S. at 597.

21. St. Antoine, supra note 4, at 78-80. See also Meltzer, The Role of Lawy in Arbitration: Rejoinders, in DEVELOPMENTS, supra note 1, at 58, 59-64. 
parties may hotly dispute not only the legality of a particular interpretation of a contract clause, but also the intended meaning of that clause. One party may be prepared to pursue the legal question through the courts. But first he wants a definitive ruling from the arbitrator on the meaning of the clause in issue. I feel he is entitled to such a ruling, uncluttered by the arbitrator's speculations about the law.

On the other hand, there is obviously a situation in which the arbitrator is entitled or even mandated to draw upon statutory or decisional sources in fashioning his award. That is when the parties call for it, either expressly or impliedly. If a contract clause, such as a union security provision, plainly tracks certain statutory language, an arbitrator is within his rights in inferring that the parties intended their agreement to be construed in accordance with the statute. Similarly, the parties may explicitly agree that they will abide by the arbitrator's interpretation of a statute whose meaning is in dispute between them. In each of these instances, I would say that technically the arbitrator's award implements the parties' agreement to be bound by his analysis of the statute, rather than by the statute itself. That distinction may have significant practical implications, as we shall see in a moment. There may be cogent reasons to avoid saddling arbitrators with the burden of statutory construction, but unless unions and employers are persuaded to refrain from imposing this responsibility, the reasons are beside the point. The choice is made by the parties, not the arbitrators. The only recourse for an adamantly objecting arbitrator is to decline such appointments.

Treating the arbitrator as the parties' designated reader of the contract enables us to resolve the thorny problem of the weight to be given an arbitrator's statutory construction. It has previously been assumed, by others as well as by me, ${ }^{22}$ that insofar as an arbitrator's award construes a statute, it is advisory only, and the statutory question will be examined de novo if the award is challenged in the courts. I no longer think this is the necessary result. As between the parties themselves, I see no impediment to their agreeing to a final and binding arbitral declaration of their statutory rights and duties. $^{23}$ Obviously, if an arbitrator's interpretation of an OSHA requirement did not adequately protect the employees or violated some

22. Feller, supra note 3, at 121-26; St. Antoine, supra note 4, at 82 .

23. Although the decisions are somewhat divided, there is clear authority that arbitrators may be made the final judges of law as well as fact, and that awards issued under a misconception of the law will be upheld. See Annot., 112 A.L.R. 873 (1938), and cases cited therein. 
other basic public policy, a court would not be bound by it. But if the arbitrator imposed more stringent requirements, I would say the award should be enforced. The parties agreed to that result, and their agreement should be accorded the same finality as any other arbitration contract.

Whatever damage may be done to the pristine purity of labor arbitration by this increased responsibility for statutory interpretation, ${ }^{24}$ I consider an expanded arbitral jurisdiction inevitable. Such recent statutes as Title VII of the Civil Rights Act of $1964,{ }^{25}$ the Pension Reform Act (ERISA), ${ }^{26}$ and OSHA ${ }^{27}$ are so interwoven in the fabric of collective bargaining agreements that it is simply impracticable in many cases for arbitrators to deal with contractual provisions without taking into account statutory provisions. Since I believe that, as between the parties, the arbitrator's rulings on the law should have the same finality as his rulings on the contract, I conclude, in contrast to the forebodings of my friend Professor Feller, that we are actually entering a new "golden age" for the arbitration process.

\section{BACKGROUND AND DEVELOPMENT OF THE Enterprise Wheel Doctrine}

In Enterprise Wheel ${ }^{28}$ the Supreme Court enunciated in sweeping terms the doctrine that the courts are not to set aside an arbitrator's decision except in certain carefully defined circumstances. Despite its inflated rhetoric, Enterprise Wheel did not mark a departure from prevailing doctrine, nor did it impart absolute finality to arbitral awards. A brief consideration of statutory and judicial attitudes toward the finality doctrine, before and after Enterprise Wheel was decided, will indicate both the broad consensus in support of the doctrine and the unwillingness to give it unqualified effect.

\section{A. Statutory and Decisional Sources}

As is well known, in section 203(d) of the Taft-Hartley Act Congress endorsed voluntary arbitration as the preferred, definitive

24. See Feller, supra note 3, at 123-26.

25. 42 U.S.C. $\$ \S 2000$ e to $2000 \mathrm{e}-17$ (1970 \& Supp. V 1975).

26. 29 U.S.C. $\S \S 1001-1381$ (Supp. V 1975).

27. Occupational Safety and Health Act of 1970, 29 U.S.C. $\S \S 651-678$ (1970).

28. Steelworkers v. Enterprise Wheel \& Car Corp., 363 U.S. 593 (1960). 
way to resolve disputes over labor contracts, stating:

Final adjustment by a method agreed upon by the parties is declared to be the desirable method for settlement of grievance disputes arising over the application or interpretation of an existing collective-bargaining agreement. ${ }^{29}$

Perhaps not so well known is that Congress has expanded the doctrine in other legislation. In a 1966 amendment to the Railway Labor Act, ${ }^{30}$ Congress provided that on court review of an award by a division of the National Adjustment Board, which arbitrates contract disputes in the railroad industry, the findings and order of the division shall be "conclusive on the parties," subject only to the following exceptions:

failure of the division to comply with the requirements of this Act, ... f failure of the order to conform, or confine itself, to matters within the scope of the division's jurisdiction, or .... fraud or corruption by a member of the division making the order. ${ }^{31}$

Both the Senate and House reports on the 1966 amendment emphasized that judicial review should be limited to "the determination of questions traditionally involved in arbitration legislation [litigation?]-whether the tribunal had jurisdiction of the subject, whether the statutory requirements were complied with, and whether there was fraud or corruption on the part of a member of the tribunal." 32 The statute says nothing about an inquiry into the merits, and the Senate report in particular makes clear that this is precluded. The Senate Labor Committee even rejected "arbitrariness or capriciousness" as a basis for setting aside an award, on the ground "such a provision might be regarded as an invitation to the courts to treat any award with which the court disagreed as being arbitrary or capricious." 33 The Committee immediately went on, however, to leave the door ajar for some judicial perusal of substance by explaining that it rejected an "arbitrary or capricious" standard "on the assumption that a federal court would have the power to decline to enforce an award which was actually and indisputably without foundation in reason or fact, and the committee intends that, under this bill, the courts will have that power." ${ }^{34}$

29. 29 U.S.C. $\$ 173$ (d) (1970) (emphasis added).

30. Pub. L. No. $89-456,80$ Stat. 208 (1966) (codified in 45 U.S.C. $\S 153$ (1970)).

31. 45 U.S.C. $\$ 153$ subd. 1(q) (1970).

32. S. REP. No. 1201, 89th Cong., 2d Sess. 6 (1966); H.R. REP. No. 1114, 89th Cong, 1st Sess. 3 (1965).

33. S. REP. No. 1201, 89th Cong., 2d Sess. 3 (1966).

34. Id. 
The United States Arbitration Act (USAA), ${ }^{35}$ the general statute providing for enforcement of arbitral awards by a federal court, can also be looked to for guidance in actions under section 301 of the Taft-Hartley Act to review arbitration awards. ${ }^{36}$ Section 10 of the USAA authorizes the vacation of awards on such grounds as fraud, corruption, partiality, procedural misconduct, exceeding of power, or absence of a final and definite award. ${ }^{37}$ Nothing is said about "gross error"- - or even, for that matter, about "utter irrationality" or "contravention of public policy." These omissions are significant, since the traditional common-law bases for vacating awards included gross mistake as well as fraud, misconduct, or want of jurisdiction. ${ }^{38}$ At the very least, the USAA constitutes further evidence of congressional endorsement of a restrictive approach to judicial review.

\section{B. The Enterprise Wheel Standard of Judicial Review}

Against the background just described, the rules set forth in Enterprise Wheel ${ }^{38}$ to govern judicial review of labor arbitration awards seem preordained. Unlike the executory agreements to arbitrate which were at issue in the other two cases of the Steelworkers Trilogy, ${ }^{40}$ and which the courts had come only slowly and grudgingly to hold legally enforceable, ${ }^{41}$ there was, as we have seen, a long,

35. 9 U.S.C. $\$ \S 1-14$ (1970).

36. See Judge Wyzanski's opinion in the leading case of Textile Workers v. American Thread Co., 113 F. Supp. 137 (D. Mass. 1953), approved and followed in Textile Workers v. Lincoln Mills, 353 U.S. 448, 451 (1957).

37. 9 U.S.C. $\S 10(1970)$.

38. D. Ziskind, Labor Arbitration Under State Statutes 3 (1943); Comment, Judicial Deference to Arbitral Determinations: Continuing Problems of Power and Finality, 23 U.C.L.A. L. REv. 936, 949-50 (1976).

In addition, the Uniform Arbitration Act, as originally promulgated in 1955, had provided for the vacation of an award when an arbitrator had "rendered an award contrary to public policy." UNIFORM ARBITRATION ACT \& 12(a)(3) (section amended 1956). The 1956 amendment omitted this provision, however, and other provisions authorizing vacation of awards so indefinite or incomplete that they could not be carried out or so grossly erroneous as to imply bad faith. See UNIFORM ARBITRATION ACr $\$ 12$ (Historical Note).

39. Steelworkers v. Enterprise Wheel \& Car Corp., 363 U.S. 593 (1960). Even if preordained, the Enterprise rules may well have had a powerful therapeutic effect. As Professor Charles J. Morris of Southern Methodist University pointed out following my delivery of this paper, many arbitral awards in his part of the country were being contested prior to Enterprise; subsequently, they were almost invariably accepted. The Midwest has apparently always been more hospitable to arbitration than the Southwest or the East. See Meltzer, supra note 1, at 12.

40. Steelworkers v. American Mfg. Co., 363 U.S. 564 (1960); Steelworkers v. Warrior \& Gulf Navigation Co., 363 U.S. 574 (1960).

41. See Gregory \& Orlikoff, The Enforcement of Labor Arbitration Agreements, 
strong tradition of judicial enforcement of awards once rendered, without review on the merits. ${ }^{42}$ Not surprisingly, then, the Supreme Court in Enterprise Wheel was prepared to state: "The federal policy of settling labor disputes by arbitration would be undermined if the courts had the final say on the merits of the awards." ${ }^{33}$ The Court spelled out the proper scope of judicial review in these words:

Nevertheless, an arbitrator is confined to the interpretation and application of the collective bargaining agreement; he does not sit to dispense his own brand of industrial justice. He may of course look for guidance from many sources, yet his award is legitimate only so long as it draws its essence from the collective bargaining agreement. When the arbitrator's words manifest an infidelity to this obligation, courts have no choice but to refuse enforcement of the award.44

Two important points should be noted about the Supreme Court's approach in Enterprise Wheel. First, the arbitrator is not limited in construing a contract to the four corners of the document. $\mathrm{He}$ is justified, for example, in "looking to 'the law' for help in determining the sense of the agreement." ${ }^{45}$ The companion Warrior \& Gulf decision is even more expansive:

The labor arbitrator's source of law is not confined to the express provisions of the contract, as the industrial common lawthe practices of the industry and the shop-is equally a part of the collective bargaining agreement although not expressed in it.46

Furthermore, insofar as the contract permits, the arbitrator is entitled to take into account "such factors as the effect upon productivity of a particular result, its consequence to the morale of the shop, his judgment whether tensions will be heightened or diminished." 47

Allowing the arbitrator to look at more than the wording of the contract is consistent with the thesis that the arbitrator is a contract reader. Contracts are written with industrial practices and psy-

17 U. CHI. L. REv. 233, 236-41, 254 (1950). The persistence of judicial hostility to the enforcement of executory agreements is exemplified by Machinists v. CutlerHammer, Inc., 297 N.Y. 519, 74 N.E.2d 464 (1947), in which New York's highest court held that a grievance must be found arguable before arbitration could be ordered. The effect was to require the courts to examine the merits in the course of determining arbitrability.

42. See, e.g., Burchell v. Marsh, 58 U.S. (17 How.) 344, 349 (1855) ("If the award is within the submission, and contains the honest decision of the arbitrators, after a full and fair hearing of the parties, a court of equity will not set it aside for error, either in law or fact"). See also cases cited in note 13 supra.

43. 363 U.S. at 596.

44. 363 U.S. at 597.

45. 363 U.S. at 598.

46. Steelworkers v. Warrior \& Gulf Navigation Co., 363 U.S. 574, 581-82 (1960).

47. 363 U.S. at 582. 
chology in mind. To decipher a contract whose literal terms do not address the problem at issue, the reader must examine the implicit as well as explicit agreements embodied in the document.

The second point to be stressed about Enterprise Wheel is that, for all its extolling of arbitration and its rejection of plenary review, the Court, like Congress, exhibits an ambivalence about how far it wishes to go in embracing finality. In insisting that an enforceable award must "draw its essence from the collective bargaining agreement" and must not, for example, be based solely upon "the requirements of enacted legislation," the Court plainly appeared to authorize some substantive examination. This is a risky invitation, because a number of courts will inevitably seize upon any opening to intervene in cases of alleged "gross error" in construction. ${ }^{48}$ As if aware of this danger, the Court in the latter portions of its opinion in Enterprise Wheel returned to the theme of finality and dismissed the argument that the arbitrator's decision was not based on the contract because his interpretation was demonstrably wrong under correct principles of contract law. ${ }^{49}$ Warrior \& Gulf was still more emphatic that "judicial inquiry under $\S 301$ must be strictly confined to the question whether the reluctant party did agree to arbitrate the grievance or did agree to give the arbitrator the power to make the award he made."so

Expectably, the lower courts in applying Enterprise Wheel have reflected the Supreme Court's ambivalence toward finality. In Safeway Stores $v$. Bakery Workers Local $111,{ }^{51}$ an arbitrator awarded employees additional pay for twenty-four hours of unperformed work on the ground the contract guaranteed forty hours' pay each week, even though the employer's payment for sixteen hours in one week resulted from a mere change in pay days and not from any loss of working time. The Fifth Circuit found that the award was based on the terms of the contract, observing bluntly: "[J]ust such a likelihood [of an 'unpalatable' result] is the by-product of a consensually adopted contract arrangement . . . The arbiter was chosen to be the Judge. That Judge has spoken. There it ends."52

On the other hand, many courts feel compelled to test an arbi-

48. See text at notes 72-75 infra.

49. Steelworkers v. Enterprise Wheel \& Car Corp., 363 U.S. 593, 598-99 (1960).

50. Steelworkers v. Warrior \& Gulf Navigation Co., 363 U.S. 574, 582 (1960).

51. 390 F.2d 79 (5th Cir. 1968).

52. 390 F.2d at 84. See UAW v. White Motor Corp., 505 F.2d 1193 (8th Cir. 1974); Machinists Dist. 145 v. Modern Air Transport, Inc., 495 F.2d 1241 (5th Cir.), cert. denied, 419 U.S. 1050 (1974); Electrical Workers (IUE) v. Peerless 
tral award against some minimum standard of rationality. Thus, even the Fifth Circuit in Safeway Stores conceded an award should be set aside "if no judge, or group of judges, could ever conceivably have made such a ruling." 53 It has also been said that the award must in some "rational way be derived from the agreement, viewed in the light of its language, its context, and any other indicia of the parties" intention," 54 that the award must not be a "capricious, unreasonable interpretation," 55 and that it must be "possible for an honest intellect to interpret the words of the contract and reach the result the arbitrator reached."56

Despite the manifest difficulties of drawing lines between what is merely "arbitrary or capricious" and what is "actually and indisputably without foundation in reason or fact," I am reluctantly prepared to accept an additional exception to the finality doctrine worded somewhat along the latter lines. Besides assuming, in their agreement on final and binding arbitration, that the arbitrator would be untainted by fraud or corruption, the parties presumably took it for granted that he would not be insane and that his decisions would not be totally irrational. Setting aside an irrational arbitral award is thus consistent with the contract reader thesis. In any event, I do not think it possible to keep courts from intervening, on one theory or another, when an arbitral award is so distorted as to reflect utter irrationality, if not temporary insanity. Indeed, in railroad cases $^{57}$ and others, ${ }^{58}$ the courts have indicated their willingness to intervene in such extreme circumstances. One need not fear that this exception to the finality doctrine opens the door to unrestrained judicial interference with arbitral awards. Although unwilling to let go of irrationality or even capriciousness as a possible basis for vacating an award, the courts are obviously uncomfortable about relying on grounds that trench so closely on the merits. They much prefer to act, as I shall next discuss, on the basis of one or the other of the better-recognized exceptions to the deference doctrine.

Pressed Metal Corp., 489 F.2d 768 (1st Cir. 1973); Butcher Workmen Local 641 v. Capital Packing Co., 413 F.2d 668 (10th Cir. 1969); Local 7-644, Oil Workers Intl. Union (AFI-CIO) v. Mobil Oil Co., 350 F.2d 708 (7th Cir. 1965).

53. 390 F.2d at 82.

54. Ludwig Honold Mfg. Co. v. Fletcher, 405 F.2d 1123, 1128 (3d Cir. 1969).

55. Holly Sugar Corp. v. Distillery Workers, 412 F.2d 899, 904 (9th Cir. 1969).

56. Newspaper Guild v. Tribune Pub. Co., 407 F.2d 1327, 1328 (9th Cir. 1969).

57. See, e.g., Gunther v. San Diego \& A.E. Ry., 382 U.S. 257, 261, 264 (1965) ("wholly baseless and completely without reason").

58. See cases cited in notes 53-56 supra. Cf. Amoco Oil Co. v. Oil Workers Local 7-1, 548 F.2d 1288, 1296 (7th Cir. 1977) (Moore, J., dissenting), cert. denied, 97 S. Ct. 1697 (1977). 


\section{Qualifications of the Deference Doctrine}

Aside from the irrationality exception, courts have described two general limitations on the deference doctrine, each consisting of several specific qualifications of the rule. The first limitation consists of jurisdictional or procedural defects. Arbitration proceedings are defective if the arbitrator oversteps his authority or compromises his neutrality or if one of the parties fails to carry out its responsibilities. The first four qualifications discussed below come under the rubric of procedural defects. The second general limitation is that a court will not enforce an arbitral award that conflicts with substantive law or public policy. The last two qualifications refer to such conflicts.

Two points with respect to these qualifications of the doctrine bear mentioning. First, courts generally strive to enforce arbitral awards; they invoke an exception to the finality doctrine only when the circumstances are compelling. Second, with the possible exception of the "modification" or "gross error" qualification, these qualifications comport with the thesis that the arbitrator is a contract reader. To set aside an arbitral award because of a procedural defect is not equivalent to finding that the arbitrator misread the contract. Rather, it represents a determination that the premises which make the arbitrator's reading reliable are not satisfied. Significantly, when a court refuses to enforce an arbitral award because of a procedural defect, the parties remain responsible for settling their initial dispute; the court does not resolve it for them. And when a court declines to enforce an arbitral award that violates law or public policy, it does not question the veracity of the arbitrator's reading of the contract; it rules that the contract as read is unenforceable.

\section{A. Lack of Arbitral Jurisdiction or Authority}

In Warrior \& Gulf, the Supreme Court demanded an "express provision excluding a particular grievance from arbitration" or else "the most forceful evidence of a purpose to exclude the claim from arbitration" before the presumption in favor of the arbitrability of all disputes concerning the interpretation of the terms of a collective bargaining agreement could be overborne. ${ }^{50}$ Nonetheless, the arbitrator remains the creature of the contract, and the parties retain the power to remove such disputes from his purview as they see fit. For example, the electrical industry has fought vigorously to restrict the 
ambit of arbitrable grievances. Thus, where an arbitration clause in an electrical manufacturer's contract explicitly excluded disputes over a merit-pay provision of the labor contract, an arbitrator was held to have exceeded his jurisdiction when he sustained a grievance based on that provision. ${ }^{60}$ The parties themselves, of course, may decide whether they wish the question of substantive arbitrability to go to the arbitrator, instead of to the court; ${ }^{61}$ if their choice is the arbitrator, the same limited standard of review should apply to his ruling on arbitrability. ${ }^{62}$

An eminently practical approach for any respondent in arbitration (ordinarily the employer) who believes the arbitrator lacks jurisdiction is to preserve explicitly his challenge to jurisdiction and to declare that his challenge will be presented to a court if there is an adverse decision on the merits. Courts respect such reservations and do not accord the resulting awards the usual presumptions of legitimacy. ${ }^{03}$

An arbitral award is also subject to judicial vacation for want of authority if it reaches beyond the boundaries of the "submission," the statement of the issue as agreed upon by the parties. For example, an arbitrator who is empowered to decide whether an employer has unreasonably increased assembly-line quotas is not authorized to order the parties to negotiate for engineering studies to guide future quota disputes. ${ }^{64}$

Arbitrators are subject to the mandate of the parties not only with regard to "subject matter" jurisdiction, but also with regard to the capacity to fashion a particular remedy. Frequently, the arbitrator will find in disciplinary cases that the employee engaged in the misconduct alleged, but that the discharge or other sanction imposed is too severe. Most courts will hold the arbitrator can reduce the penalty in these circumstances, e.g., to a suspension of specified length or to reinstatement without back pay. Often the rationale is that the arbitrator properly concluded that the heavier penalty was

60. Electrical Workers (IUE) Local 278 v. Jetero Corp., 496 F.2d 661 (5th Cir. 1974).

61. See Steelworkers v. Warrior \& Gulf Navigation Co., 363 U.S. 574, 582-83 \& n.7 (1960).

62. See Steelworkers v. United States Gypsum Co., 492 F.2d 713, 732 (5th Cir.), cert. denied, 419 U.S. 998 (1974).

63. Local 719, American Bakery Workers v. National Biscuit Co., 378 F.2d 918 (3d Cir. 1967); Trudon \& Platt Motors Lines, Inc. v. Teamsters Local 707, 71 L.R. R.M. 2814 (S.D.N.Y. 1969).

64. Local 791, Intl. Union of Elec. Workers (IUE) v. Magnavox Co., 286 F.2d 465 (6th Cir. 1961). See also Retail Store Employees Local 782 v. Sav-On Groceries, 508 F.2d 500 (10th Cir. 1975). 
without "just cause." ${ }^{\circ 5}$ But if the employer secures a contract clause denying the arbitrator the power to modify discipline, this will ordinarily be enforced by the courts. ${ }^{66}$

Perhaps the most dramatic illustration of a court's willingness to sustain an arbitrator's remedial powers, despite contractual limitations on his authority to "add to, detract from, or alter in any way the provisions of this contract," is provided by Steelworkers $v$. United States Gypsum Co. ${ }^{67}$ Distinguishing Supreme Court precedent restricting NLRB remedies in analogous situations, the Fifth Circuit held that an arbitrator could award wage increases based on his projections of the wage settlement that would have been reached if the employer had not violated its duty to bargain under the wage reopener clause in a labor contract.

\section{B. Arbitral "Modifications" or "Gross Error"}

Collective bargaining agreements often provide that an arbitrator may not "add to, modify, or otherwise alter the terms of this contract." Such language paves the way for what is probably the most troublesome of all assaults on arbitral finality. Torrington v. Metal Products Workers Local $1645^{68}$ is the classic case. Prior to the negotiation of a new contract, an employer unilaterally announced the discontinuance of a long-standing practice to pay employees for one hour away from work on Election Day. An arbitrator sustained the union's grievance, finding that the past practice could be terminated only by mutual agreement. The Second Circuit refused enforcement, declaring that "the mandate that the arbitrator stay within the confines of the collective bargaining agreement . . . requires a reviewing court to pass upon whether the agreement authorizes the arbitrator to expand its express terms on the basis of the parties' prior practice." $8 \theta$ A dissenting judge argued that the court was improperly reviewing the merits and that the arbitrator was entitled to look to "prior practice, the conduct of the negotiation for the new contract and the agreement reached at the bargaining table to reach his con-

65. E.g., Campo Mach. Co. v. Machinists Local 1926, 536 F.2d 330 (10th Cir. 1976); Machinists Dist. 8 v. Campbell Soup Co., 406 F.2d 1223 (7th Cir. 1969); Lynchburg Foundry Co. v. Steelworkers Local 2556, 404 F.2d 259 (4th Cir. 1968).

66. See, e.g., Amanda Bent Bolt Co. v. UAW Local 1549, 451 F.2d 1277 (6th Cir. 1971); Truck Drivers Local 784 v. Ulry-Talbert Co., 330 F.2d 562 (8th Cir. 1964). But cf. Painters Local 1179 v. Welco Mfg. Co., 93 L.R.R.M. 2589 (8th Cir. 1976).

67. 492 F.2d 713 (5th Cir.), cert. denied, 419 U.S. 998 (1974).

68. 362 F.2d 667 (2d Cir. 1966).

69. 362 F.2d at 680 . 
clusion that paid time off for voting was 'an implied part of the contract." "70

The difficulty is that any time a court is incensed enough with an arbitrator's reading of the contract and such supplementary data as past practice, bargaining history, and the "common law of the shop," it is simplicity itself to conclude that the arbitrator must have "added to or altered" the collective bargaining agreement. How else can one explain this abomination of a construction? Yet if the courts are to remain faithful to the injunction of Enterprise Wheel, they must recognize that most arbitral aberrations are merely the product of fallible minds, not of overreaching power. ${ }^{71}$ At bottom, there is an inherent tension (if not inconsistency) between the "final and binding" arbitration clause and the "no additions or modifications" provision. The arbitrator cannot be effective as the parties' surrogate for giving shape to their necessarily amorphous contract unless he is allowed to fill the inevitable lacunae.

"Gross error" is another accepted common-law ground for setting aside arbitrations awards. In Electronics Corp. of America $v$. Electrical Workers (IUE) Local $272,{ }^{72}$ an award was vacated because "the central fact underlying an arbitrator's decision [was] concededly erroneous."73 There the arbitrator had assumed, contrary to the evidence as presented to the court, that an aggrieved employee had not been suspended previously by the employer. Similarly, in Northwest Airlines, Inc. v. Air Line Pilots Association, ${ }^{74}$ the court refused enforcement of an award that was based on the arbitration panel's mistaken belief that the meaning of "pilot seniority list" in a letter from the company to the union was agreed to by both parties as not including furloughed pilots in addition to active ones. Other courts, however, have been more rigorous in adhering to the Enterprise Wheel and Warrior \& Gulf standards. Thus the Third Circuit declared in Bieski v. Eastern Auto Forwarding Co.:

If the court is convinced both that the contract procedure was intended to cover the dispute and, in addition, that the intended procedure was adequate to provide a fair and informed decision, then

70. 362 F.2d at 683 (Feinberg, J., dissenting). See also H.K. Porter Co. v. Saw Workers Local 22254, 333 F.2d 596 (3d Cir. 1964). Torrington was roundly criticized in Aaron, Judicial Intervention in Labor Arbitration, 20 STAN. L. REv. 41 (1967); Meltzer, supra note 1, at 9-11.

71. See R. Gorman, Basic Text on Labor LaW: Unionization and Collfetive Bargaining 593 (1976).

72. 492 F.2d 1255 (1st Cir. 1974).

73. 492 F.2d at 1256.

74. 530 F.2d 1048 (D.C. Cir. 1976). 
review of the merits of any decision should be limited to cases of fraud, deceit, or instances of unions in breach of their duty of fair representation. ${ }^{75}$

\section{Procedural Unfairness or Irregularity}

Fraud and corruption are universal bases for invalidating an award. So is bias or partiality, which may consist of improper conduct at the hearing ${ }^{76}$ or an association with one party that is not disclosed to the other. ${ }^{77}$

Much less common is the vacation of an award because of an unfair and prejudicial exclusion or admission of evidence. Hearsay of course is ordinarily acceptable in arbitration proceedings, and arbitrators are accorded considerable latitude in their evidentiary determinations. ${ }^{78}$ It is the excessively technical, unexpected, and hurtful ruling that is likely to trigger judicial intervention. In the interest of fostering finality, courts will rarely overturn an award on the basis of new evidence not introduced at the hearing. ${ }^{79}$

\section{Individual Rights}

It is well established that a union "may not arbitrarily ignore a meritorious grievance or process it in a perfunctory fashion." ${ }^{\text {so }}$ If a union so violates its duty of fair representation, an adversely affected employee is relieved of the obligation to exhaust grievance and arbitration procedures, and any arbitral award loses the finality it would otherwise possess.

A striking demonstration of this latter principle is Hines $v$. Anchor Motor Freight, Inc. ${ }^{81}$ Trucking employees were discharged for alleged dishonesty in seeking excessive reimbursement for lodging

75. 396 F.2d 32, 38 (3d Cir. 1968). See also Aloha Motors, Inc. v. ILWU Local 142, 530 F.2d 848 (9th Cir. 1976).

76. Holodnak v. Avco Corp., 381 F. Supp. 191 (D. Conn. 1974), modified on other grounds, 514 F.2d 285 (2d Cir.), cert. denied, 423 U.S. 892 (1975).

77. Colony Liquor Distrib., Inc. v. Local 669, Intl. Bhd. of Teamsters, 34 App. Div. 2d 1060, 312 N.Y.S.2d 403 (1970), aff'd., 28 N.Y.2d 596, 268 N.E.2d 645, 319 N.Y.S.2d 849 (1971).

78. See R. Gorman, supra note 71, at 599-603, and cases cited therein.

79. See id. at 601-02.

80. Vaca v. Sipes, 386 U.S. 171, 191 (1967). See also Republic Steel Corp. v. Maddox, 379 U.S. 650, 652 (1965); Humphrey v. Moore, 375 U.S. 335 (1964).

81. 424 U.S. 554 (1976). See also Bieski v. Eastern Auto Forwarding Co., 396 F.2d 32 (3d Cir. 1968). Cf. Roadway Express, Inc., 145 N.L.R.B. 513, 515 (1963); Spielberg Mfg. Co., 112 N.L.R.B. 1080, 1082 (1955). But cf. Hotel Employees v. Michelson's Food Serv., 94 L.R.R.M. 2014 (9th Cir. 1976) (employee's mere objection to arbitration insufficient). 
expenses. The employer presented motel receipts submitted by the employees which exceeded the charges shown on the motel's books. Arbitration sustained the discharges. Later, evidence was secured indicating that the motel clerk was the culprit, having recorded less than was actually paid and pocketing the difference. In a suit by the employees against the employer, the Supreme Court held that the employer could not rely on the finality of the arbitration award if the union did not fairly represent the employees in the arbitration proceedings. Such a rule can hardly be faulted as an abstract proposition. But the results could be mischievous if the courts become too quick to equate a halting, inexpert arbitration presentation by a lay union representative with "bad faith" or "perfunctoriness."

\section{E. Violation of Law or Public Policy}

As I have urged earlier, ${ }^{82}$ and as I believe Enterprise Wheel itself commands, ${ }^{83}$ an arbitrator confronted with an irreconcilable conflict between the terms of a collective bargaining agreement and the apparent requirements of statutory or decisional law should follow the contract and ignore the law. But the parties to any contract will not be able to secure judicial enforcement if their agreement is illegal or otherwise contrary to public policy. Similarly, the court will not enforce an arbitral award that either sustains or orders conduct violative of law or substantial public policy.

Such an approach involves no infidelity to Enterprise Wheel. When a legal challenge is mounted to an award, a court "is concerned with the lawfulness of its enforcing the award and not with the correctness of the arbitrator's decision." 84 In effect, the court is assuming the soundness of the arbitrator's reading of the parties' agreement and is proceeding to test the validity and enforceability of the award just as if it were a stipulation by the parties as to their intended meaning.

In entertaining legal challenges to arbitral awards, the courts have had to consider the impact of a wide variety of federal and state

82. See text following note 19 supra.

83. Steelworkers v. Enterprise Wheel \& Car Corp., 363 U.S. 593, 597 (1960).

84. Local 985, UAW v. W.N. Chace Co., 262 F. Supp. 114, 117 (E.D. Mich. (1966) (emphasis original), quoted in Botany Indus. v. New York Joint Bd., Amalgamated Clothing Workers, 375 F. Supp. 485, 490 (S.D.N.Y.), vacated on other grounds, 506 F.2d 1246 (2d Cir. 1974). See Newspaper Guild Local 35 v. Washington Post Co., 442 F.2d 1234, 1239 (D.C. Cir. 1971); Glendale Mfg. Co. v. Local S20, ILGWU, 283 F.2d 936 (4th Cir. 1960), cert. denied, 366 U.S. 950 (1961). 
laws. These have ranged from the Sherman $\mathrm{Act}^{85}$ to the anti-kickback provisions of Taft-Hartley's section $302^{80}$ to state protective legislation. ${ }^{87}$ Most often, arbitral awards have been attacked on the ground they approve or direct the commission of an unfair labor practice in violation of the National Labor Relations Act. Despite some forceful argument that a court in such cases should defer to the National Labor Relations Board, ${ }^{88}$ it is now the general view, I think rightly, that a court ought not to sanction illegal conduct, even though that means it must boldly step into the unfair labor practice thicket. After all, federal district courts make preliminary determinations of what constitutes an unfair labor practice in handling applications for injunctive relief under section $10(j)$ and $10(1)$ of the National Labor Relations Act. ${ }^{89}$ In addition, federal courts of appeals routinely review NLRB decisions, and state courts are ultimately subject to Supreme Court oversight.

In passing upon unfair labor practices potentially lurking in arbitral awards, the courts have not even shrunk from tangling with the intricacies of NLRA section 8(e)'s hot-cargo ban. ${ }^{90}$ Probably more frequent, however, is the situation where the arbitral award would have a coercive or "chilling" effect on employees' protected activities. ${ }^{01}$ The easiest case, naturally, is where the Labor Board has already acted by the time the court is asked to vacate the award. Thus, in Glendale Manufacturing Co. v. ILGWU Local 520,02 the court refused to enforce an arbitrator's bargaining order against an employer when, shortly after the award was issued, the union was defeated in a Board certification election. ${ }^{93}$

85. See Associated Milk Dealers v. Milk Drivers Local 753, 422 F.2d 546 (7th Cir. 1970).

86. See Steelworkers v. United States Gypsum Co., 492 F.2d 713 (5th Cir.), cert. denied, 419 U.S. 998 (1974).

87. See UAW Local 985 v. W.M. Chace Co., 262 F. Supp. 114 (E.D. Mich. 1966). But cf. UAW v. Avco Tycoming Div., 66 Lab. Cas. 111922 (D. Conn. 1971) (state law probably invalid under 1964 Civil Rights Act).

88. See Sovern, Section 301 and the Primary Jurisdiction of the NLRB, 76 HARv. L. REv. 529, 561-68 (1963) (citing Retail Clerks Locals 128 \& 633 v. Lion Dry Goods, Inc., 369 U.S. 17 (1962)). But cf. Aaron, supra note 70, at 53; Meltzer, supra note 1 , at 17 n.40.

89. 29 U.S.C. $\S 160(\mathrm{j}), 160(l)(1970)$.

90. Compare Botany Indus. v. New York Joint Bd., Amalgamated Clothing Workers, 375 F. Supp. 485 (S.D.N.Y.), vacated on other grounds, 506 F.2d 1246 (2d Cir. 1974), with La Mirada Trucking, Inc. v. Teamsters Local 166, 92 L.R.R.M. 3524 (9th Cir. 1976).

91. See Dries \& Krump Mfg. Co. v. NLRB, 93 L.R.R.M. 2739 (7th Cir. 1976); Hawaiian Hauling Serv. v. NLRB, 93 L.R.R.M. 2952 (9th Cir. 1976), cert. denied, 97 S. Ct. 2921 (1977).

92. 283 F.2d 936 (4th Cir. 1960), cert. denied, 366 U.S. 950 (1961).

93. Cf. Carey v. Westinghouse Elec. Corp., 375 U.S. 261 (1964) (arbitration appropriate since dispute was not within the exclusive jurisdiction of the NLRB). 
A more nebulous ground for vacating an award is that it is contrary to "public policy." A court must resist the temptation to employ this rubric as a device for asserting its own brand of civic philosophy. Invariably cited as an example of such behavior is the McCarthy-era case of Black $v$. Cutter Laboratories. ${ }^{94}$ Cutter fired a communist employee, allegedly because of her party membership. An arbitration panel held the real reason for the discharge was her union activity and ruled this was not "just cause." The California Supreme Court set aside the award, declaring that "an arbitration award which directs that a member of the Communist Party who is dedicated to that party's program of 'sabotage, force, violence and the like' be reinstated to employment in a plant which produces antibiotics . . . is against public policy."95

Local 453, International Union of Electrical Workers v. Otis Elevator $\mathrm{Co}^{96}$ reflects a more enlightened attitude. An employee was discharged for violating a company rule against gambling after he had been convicted and fined for "policy" trafficking in the plant. The arbitrator found him guilty but reduced the discharge to reinstatement without back pay for seven months, emphasizing his good work record, family hardship, and other factors. In upholding the arbitral award, the Second Circuit observed that the suspension and criminal fine vindicated the state's antigambling policy and that the reinstatement was in accord with the public policy of criminal rehabilitation. Otis Elevator of course does not reject public policy as a basis for vacating arbitral awards, but it does caution against an overzealous resort to it..$^{97}$

\section{F. Independent Statutory Claims Following Arbitration}

A new dimension was added to the relationship between the courts and arbitrators by the Supreme Court's 1974 decision in Alexander v. Gardner-Denver Co. ${ }^{98}$ In this case the Court held that an individual employee whose claim of racial discrimination was denied by the ruling of an arbitrator appointed pursuant to the contract was not thereby precluded from suing his employer under Title VII

94. 43 Cal. 2d 788, 278 P.2d 905, cert. granted, 350 U.S. 816 (1955), cert. dismissed, 351 U.S. 292 (1956).

95. 43 Cal. $2 \mathrm{~d}$ at 798-99, 278 P.2d at 911. See also Goodyear Tire \& Rubber Co. v. Sanford, 92 L.R.R.M. 3492 (Tex. Ct. App. 1976).

96. 314 F.2d 25 (2d Cir.), cert. denied, 373 U.S. 949 (1963).

97. See also Machinists Dist. 8 v. Campbell Soup Co., 406 F.2d 1223 (7th Cir. 1969).

98. 415 U.S. 36 (1974). 
of the 1964 Civil Rights Act. The Court emphasized that in the arbitration proceedings the employee was pursuing contractual claims, while in the court suit he was asserting independent statutory rights. Although recognizing the analogy to discrimination charges filed with the NLRB following an adverse arbitral decision on a discrimination grievance, the Court refused to follow the deferral standard adopted by the Labcr Board in Spielberg Manufacturing Co." Instead, the Court concluded that a federal court should consider the employee's Title VII claim de novo. The Court added, however, that the "arbitral decision may be admitted as evidence and accorded such weight as the court deems appropriate." ${ }^{\text {"100 }}$ This qualification was elaborated on in the now-famous footnote 21 , which stated, inter alia:

Where an arbitral determination gives full consideration to an employee's Title VII rights, a court may properly accord it great weight. This is especially true where the issue is solely one of fact, specifically addressed by the parties and decided by the arbitrator on the basis of an adequate record. ${ }^{101}$

The Gardner-Denver distinction between deference in NLRA cases and nondeference in Title VII cases seems supportable on at least two grounds. First, racial discrimination (as well as religious and sex discrimination) presents peculiarly sensitive and difficult problems. Their solution has received the highest priority. Second, the NLRA deals essentially with collective rights, while Title VII deals essentially with individual rights. It therefore is more appropriate that a union and an employer should be able to make a final and binding settlement, or provide for its equivalent through arbitration, with regard to collective rights than with regard to individual rights. In Satterwhite v. United Parcel Service, Inc., ${ }^{102}$ the Tenth

99. 112 N.L.R.B. 1080, 1082 (1955) (NLRB will defer to arbitral award when "the proceedings appear to have been fair and regular, all parties had agreed to be bound, and the decision of the arbitration panel is not clearly repugnant to the purposes and policies of the Act"). In Electronic Reproduction Serv. Corp., 213 N.L. R.B. 758, 87 L.R.R.M. 1211 (1974), a 3-2 Board majority extended the deferral doctrine in discipline cases to unfair labor practice issues that could have been, but in fact were not, submitted to the arbitrator. But cf. General Am. Transp. Corp., 228 N.L.R.B. No. 102, 94 L.R.R.M. 1483 (1977), which overruled National Radio Co., 198 N.L.R.B. 528, 80 L.R.R.M. 1718 (1972), and thereby abrogated the Collyer prearbitration deferral doctrine insofar as it applied to individual $\$ 8(a)(1)$ and $\$$ 8 (a) (3) coercion and discrimination charges. For the time being at least, the Board will continue the Collyer policy of deferring to contractual arbitration machinery in $\$ 8($ a) (5) unilateral action cases. See Roy Robinson Chevrolet, 228 N.L.R.B. No. 103, 94 L.R.R.M. 1474 (1977) (following Collyer Insulated Wire, 192 N.L.R.B. 837 (1971)).

100. 415 U.S. at 60 .

101. 415 U.S. at 60 n.21.

102. 496 F.2d 448 (10th Cir.), cert. denied, 419 U.S. 1079 (1974). 
Circuit relied on both these points in declining to examine de novo under the Fair Labor Standards Act certain wage claims that had previously been the subject of an adverse arbitration award. ${ }^{103}$

None of this bears directly on judicial review of arbitral awards. But Satterwhite surely suggests a receptivity to enforcement of awards involving statutory issues, at least "when the arbitral and judicial proceedings arise out of, and must be decided on, the same factual background."104 Even on Title VII questions, which may be sui generis, I find myself more inclined to side with Theodore Sachs ${ }^{105}$ than with Professors Harry Edwards ${ }^{100}$ or Bernard Meltzer $^{107}$ concerning arbitrator participation-always assuming, of course, the implicit or explicit authorization of the parties. Even though the arbitration award on a Title VII issue cannot be conclusive, or even technically entitled to "deference," it may end the dispute. The employee may prevail. Or the evidence adduced may be so overwhelming that the employee concedes. At any rate, in the usual discharge or disciplinary case, it would be highly artificial, if not impossible, for the arbitrator to separate out Title VII considerations if race or sex or religious discrimination is one of the grievances under the contract. I hear the objections to arbitrators' legal competence, and I have mouthed them myself on occasion, but I think they are make-weights, at least in the civil rights area. "Discrimination" is a simple concept, however subtle and elusive; it is not the Internal Revenue Code. To paraphrase Justice Holmes, the only reason the courts look so smart in dealing with it is that they come along at a later stage in the decisionmaking process. If an arbitrator had ever come up with Washington $v$. Davis, ${ }^{108}$ the Supreme Court decision restricting the "effects" test to Title VII cases

103. 496 F.2d at $450-51$. The result in Satterwhite may well be erroneous, but that is immaterial for my purposes.

104. $496 \mathrm{~F} .2 \mathrm{~d}$ at $451-52$.

105. See Sachs, Comment-The Coming End of Arbitration's Golden Age, in ARBITRATION-1976, supra note 3, at 127, 130-31.

106. See Edwards, supra note 2.

107. See Meltzer, Arbitration and Discrimination-The Parties' Process and the Public's Purposes, in ARBITRATION-1976, supra note 3, at 46.

108. 426 U.S. 229 (1976). In Griggs v. Duke Power Co., 401 U.S. 424 (1971), the Supreme Court held that Title VII of the Civil Rights Act of 1964, 42 U.S.C. $\$ \S 2000$ e to $2000 \mathrm{e}-17$ (1970), outlawed employment practices with consequences disproportionately detrimental to minorities, even though there was no intention to discriminate. In the Washington case, however, the Court declared that governmental action does not violate the due process or equal protection clauses of the Federal Constitution if there is no racially discriminatory purpose, despite a disproportionately adverse impact on minority employees. 
and requiring invidious intent in constitutional cases, the critics would have stoned him (or even her).

Court decisions subsequent to Gardner-Denver confirm that arbitration of civil rights discrimination claims is not a futility. In $E E O C$ v. McLean Trucking Co. ${ }^{109}$ for example, the Sixth Circuit held that a successful grievant may not accept the arbitration award and then sue for additional private benefit. He may, however, profit along with other employees from any changes secured by the EEOC in a suit brought on the grievant's charge for the public benefit. And in Swint $v$. Pullman-Standard, ${ }^{110}$ a federal district court in a suit under the 1866 Civil Rights Act was persuaded in part by an arbitration award that the discharge of one employee and the suspension of another were not racially motivated. Similarly, in Communications Workers $v$. Mountain States Telephone \& Telegraph Co., ${ }^{111}$ a federal district court gave heavy weight to the delicately poised accommodation worked out by the arbitrator between an affirmative action "override" in a consent decree and the seniority system in a collective bargaining agreement. ${ }^{112}$

\section{Conclusion}

The grievance arbitrator is the parties' designated definitive reader of their labor contract. What he reads is, by reason of their agreement and not by any peculiarity of the collective bargaining process, what they meant to write. "Gross error" or "misrepresentation" by this reader is a contradiction in terms. An award is other than the parties' own putative agreement only if the arbitrator is untrue to his charge, or dishonest, or unfair, or perhaps totally irrational. An arbitrator must find the essence of his award in the parties' agreement, but that may include, implicitly or explicitly, an authorization for him to draw upon a range of other sources, including statutory and decisional law.

A court asked to review or enforce an arbitral award can relax about the merits. By definition, the award is the parties' stipulated, adopted contract. The only conditions are procedural, not substantive-jurisdiction, authority, honesty, fairness, and basic rationality. Before granting enforcement, the court ordinarily need only concern itself with the legality of the award, just as it would have to concern

109. 525 F.2d 1007 (6th Cir. 1975).

110. 11 Fair Empl. Prac. Cas. 943 (N.D. Ala. 1975).

111. No. 75-P-245 (D. Colo. Jan. 14, 1977).

112. Mountain States Tel. \& Tel. Co., 64 Lab. Arb. 316 (1974) (Platt, Arb.). 
itself with the legality of any contract. The only exceptions are when substantial rights of third parties, such as individual employees, intervene. Unfair representation by a union may invalidate an award. An arbitral award cannot bar a suit based on a highly sensitive, individual, independent statutory right, such as the right to be free from racial, sexual, or religious discrimination. But in the absence of some adverse impact on such individual rights or on third parties, an arbitrator's interpretation of either contract or external law should have the same finality as between the union and the employer.

Professor Feller is correct in pointing out that the courts have not deferred to arbitral awards because arbitrators have a peculiar expertise or because they are especially efficient. ${ }^{113}$ But his effort to pin this deference on a distinction between arbitration as rulemaking and adjudication as rule-application ultimately fails. Undoubtedly, much of arbitration is concerned with filling in the gaps in the parties' agreement through a process that looks more like rulemaking than rule-application. But this is not invariably the case. Recently $I$ handled an arbitration that turned on a delicious question about the meaning of "and/or" in a labor agreement. No court, and no first-year contracts class in law school, would have found that unfamiliar terrain. In addition, as I mentioned earlier, arbitrators often find it necessary to apply statutory law in order to construe contractual language. Conversely, whenever a court must tackle such protean terms as "due process" and "equal protection" in constitutional litigation or a whole variety of "fair" and "reasonable" tests in statutory contexts, I would insist it is engaged in much the same sort of exercise as an arbitrator wrestling with "just cause" in a labor agreement.

If it is true in any sense that arbitrators are leaving behind a golden age, because they no longer speak as oracles in a sovereign world of industrial jurisprudence but instead as one of several tribunals in the new statutorily regulated dominion of labor relations, it is only in the sense that they are exchanging the primitive simplicities of ancient Greece for the sophisticated glories of the High Renaissance. 